\title{
Relationship of Ferritin Levels and Vitamin B12 Levels Pregnant Women Anemia on Baby Birth Weight
}

\author{
Citra Dewi Anitasari', Arni Amir ${ }^{2}$, Defrin $^{3}$ \\ ${ }^{I}$ Master of Midwifery, Faculty of Medicine, Andalas University, Padang \\ ${ }^{2}$ Subdivision Obstetry and GynekologyFaculty of Medicine, Andalas University, Padang \\ ${ }^{3}$ Subdivision Hematologyand Onkology Medic Faculty of Medicine, Andalas University, Padang
}

\begin{tabular}{|c|c|}
\hline SUBMISSION TRACK & A B S T R A C T \\
\hline Recieved: & \\
\hline Final Revision: & Anemia in pregnancy is a health problem that usually \\
\hline Available Online: & $\begin{array}{l}\text { occurs throughout the world. In developing countries, } \\
\text { anemia during pregnancy is due to micronutrient }\end{array}$ \\
\hline KEYWORDS & deficiencies such as iron, vitamin B12 and folic acid. \\
\hline $\begin{array}{l}\text { Feritin, Vitamin B12, Anemia, Baby birth } \\
\text { weight }\end{array}$ & $\begin{array}{l}\text { study were all anemic pregnant women who came to } \\
\text { Lubuk Buaya Health Center. The sample in this study } \\
\text { based on inclusion criteria totalling } 40 \text { respondents } \\
\text { taken by consecutive sampling technique. }\end{array}$ \\
\hline CORRESPONDENCE & Examination of ferritin and vitamin B12 levels was \\
\hline $\begin{array}{l}\text { Phone : } 081378487359 \\
\text { E-mail : citranasution3@gmail.com }\end{array}$ & $\begin{array}{l}\text { carried out at the Andalas University Biomedical } \\
\text { Laboratory using the ELISA method. Statistical test } \\
\text { was performed using SPSS, normality test with } \\
\text { Shapiro Wilk andSpearman test to see the } \\
\text { relationship between ferritin and vitamin B12 levels } \\
\text { to the baby's birth weight.The results of this study } \\
\text { showed that the mean ferritin level of anemia } \\
\text { pregnant woman with baby birth weight was } 11.13 \pm \\
6.37 \text { with a value of } p>0.05, r=0.280 \text { and the mean } \\
\text { vitamin B12 levels of anemic pregnant women with } \\
\text { birth weight were } 299,53 \pm 98.46 \text { with a value of p> } \\
0.05, r=0.161 \text {. The conclusion of this study was that } \\
\text { there is a non significant positive relationship } \\
\text { between ferritin and vitamin B12 levels on the birth } \\
\text { weight of the baby. It is recommended that pregnant } \\
\text { women keep on consuming Fe tablets during } \\
\text { pregnancy and further study is necessary to see } \\
\text { pregnant woman adherence in consuming Fe tablets. }\end{array}$ \\
\hline
\end{tabular}




\section{INTRODUCTION}

Anemia is a health problem that occurs in developing and developed countries. About 1.62 billion people experience anemia worldwide (WHO, 2011). Pregnant women are the group most susceptible to anemia which can adversely affect the mother and fetus. Various studies have shown that $30.3 \%$ of causes of maternal death due to bleeding at the time of childbirth and anemia during the pregnancy period are important precipitating factors that indirectly become the cause of maternal death (Data and Information Center of the Ministry of Republic of Indonesia, 2014). Anemia during pregnancy also causes premature birth, low birth weight babies, fetal disorders and infant mortality (Gebre \& Mulugeta, 2015).

According to the World Health Organization (WHO) in 2011 the incidence of anemia during pregnancy was around $41.8 \%$ in the world while in Southeast Asia pregnant women who experienced anemia were 51.2\%. According to the 2007 Basic Health Study (RISKESDAS) pregnant women who experienced anemia in Indonesia at $24.5 \%$ this figure increased in 2013 to $37.1 \%$. (Ministry of Health of the Republic of Indonesia, 2014).

Anemia during pregnancy in West Suamatra in 2016 was $23.8 \%$ and anemia in Padang City in 2014 amounted to $13.5 \%$ this figure increased compared to 2010 amounted to $7.32 \%$ with the highest percentage of anemia occurring in the Working Area of Lubuk Buaya Health Center 17.6\% (Padang City Health Office, 2015; Provincial Health Office of West Sumatra, 2015).

Anemia is a condition in which the reduction of red blood cells (erythrocytes) in the blood circulation or hemoglobin mass so that it is unable to fulfill its function as an oxygen carrier throughout the network (Tarwoto and Wasnidar, 2007). According to WHO (2011) iron is a common cause of anemia but in addition to iron other nutritional deficiencies such as vitamin B12, vitamin $\mathrm{C}$, folic acid and vitamin $\mathrm{A}$ can also cause anemia.

Iron is part of the hemoglobin molecule, with reduced iron, the synthesis of hemoglobin will decrease and the hemoglobin level will decrease. Hemoglobin is an element that is vital for the human body, because low hemoglobin levels affect the ability to deliver oxygen $\left(\mathrm{O}_{2}\right)$ which is needed by all body tissues. Iron with vitamin B12 is also one of the ingredients of erythrocyte formation (Sherwood, 2011; Tarwoto and Wasnidar, 2007).

Anemia in pregnancy is a condition where there is a lack of red blood and a decrease in hemoglobin is less than $11 \mathrm{~g} \%$. In the first and third trimesters Hemoglobin levels are less than $11 \mathrm{gr} \%$, in the second trimester hemoglobin levels are less than $10.5 \mathrm{~g} \%$ (Breyman, 2013).

The body's need for vitamin B12 is as important as iron minerals. Vitamin B12 together with iron functions as an ingredient in the formation of red blood cells. Vitamin B12 deficiency not only triggers anemia but can also interfere with the nervous system. Vitamin B12 deficiency can occur due to interference from the body or external causes. The digestive tract will absorb all the nutrients in food including vitamin B12 (Citrakesumasari, 2012).

Vitamin B12 besides playing a role in erythrocyte synthesis also plays an important role in DNA replication, keeping the myelin sheath that surrounds nerve cells and plays an important role in the proliferation of cells, especially the placenta and fetus, which divides rapidly during the pregnancy period (Samuel, 2013). Vitamin B12 gradually 
decreases during the pregnancy period from the first to the third trimester due to hemodilution and peaks at 32 weeks and before birth, then returns to normal after delivery. Mothers who experience vitamin B12 deficiency during pregnancy are at risk of delivering low birth weight babies (Van et al, 2013).

Third trimester pregnancies often occur in conditions of iron deficiency anemia (ADB) because at that time the fetus stockpiled iron reserves for itself as a supply immediately after birth. ADB pregnancy can be seen by measuring ferritin levels. Ferritin is a protein envelope, serum concentration associated with total iron reserves. As pregnancy increases, the first trimester ferritin level drops to $32 \%$, second trimester $39 \%$ and third trimester 53\%. Decreased ferritin levels are associated with a decrease in maternal iron reserves as a result of increased absorption (by the mother and fetus) and hemodilution (Visnjevac, 2011).

Study related to ferritin concentration and pregnancy: linear model to predict birth weight and birth length by Vjirinejad (2007) showed that there was a significant relationship between maternal serum ferritin concentration on infant body weight $(\mathrm{r}=$ $0.434, \mathrm{n}=120, \quad p<0.001)$ and the relationship between folic acid and vitamin B12 mothers with birth weight and body proportions of newborns by Ahmed et al (2011) showed that there was a significant relationship between low serum vitamin B12 levels and the incidence of low birth weight $(\mathrm{r}=0.512, p<0,000)$.

Various policies have been implemented in the context of early detection and treatment of anemia during pregnancy, given the adverse effects caused by anemia, one of which is theprogram, making safer pregnancy namely the examination of hemoglobin levels at the First Visit (K1) (Ministry of Health, 2014). However, in reality the problem cannot be solved optimally because the cause of anemia is not only caused by iron deficiency but can also be caused by other micronutrient deficiencies (vitamin B12, Vitamin C, folic acid and vitamin $\mathrm{A}$ ) despite the fact that $\mathrm{ADB}$ is the most good anemia in developed and developing countries. Therefore, it is necessary to measure ferritin and serum levels of vitamin B12 in order to add information related to anemia of pregnancy to the community and appropriate treatment of anemia in accordance with the causes of micronutrient deficiency (Scholl, 2011; WHO, 2011).

\section{METHODS}

This was an analytical study with a cross sectional design totalling 40 respondents of anemic pregnant women in the working area of Lubuk Buaya Health Center in 2017. Data collection was carried out by taking $3 \mathrm{cc}$ of maternal blood then centrifuge and the serum was stored at $-20^{\circ}$ until samples were met and then examined Ferritin and Vitamin B12 with ELISA. Data was performed using SPSS with Spearman Correlation Test.

\section{RESULTS}

Table 1. Average ferritin and vitamin B12anemia and infant birth weight

\begin{tabular}{|c|c|c|c|}
\hline Variable & $\mathbf{n}$ & Mean $\pm S D$ & $\begin{array}{c}\text { Minimum - } \\
\text { Maximal }\end{array}$ \\
\hline $\begin{array}{c}\text { levels } \\
\text { ofFerritin } \\
\text { Level }\end{array}$ & 40 & 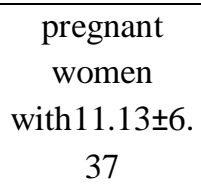 & $3.91-26.10$ \\
\hline Vitamin B12 & 40 & $\begin{array}{c}299.53 \pm \\
98.46\end{array}$ & $\begin{array}{c}172.33- \\
586.75\end{array}$ \\
\hline $\begin{array}{c}\text { Baby Birth } \\
\text { Weight }\end{array}$ & 40 & $\begin{array}{l}3127 \pm \\
292.63\end{array}$ & $2300-3600$ \\
\hline
\end{tabular}




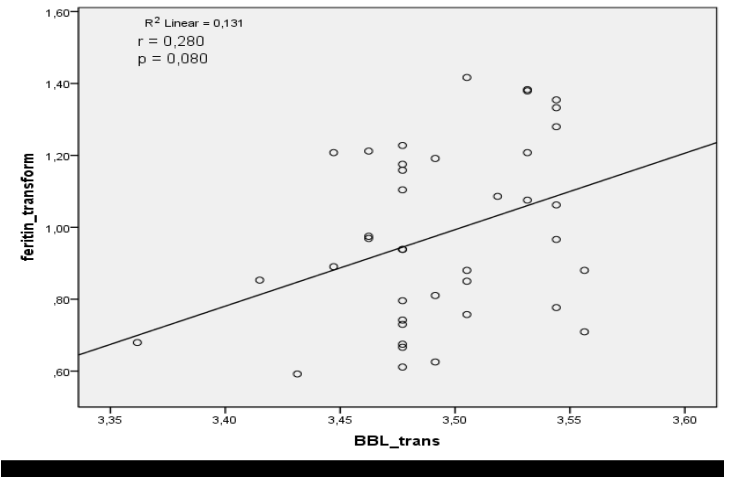

Figure 1. Scatter Plot Relationship Between Ferritin Levels of Pregnant Women Anemia with Baby Weight Birth Bari

Based on the picture above it can be seen that there is no relationship between ferritin levels of anemic pregnant women with birth weight (value $\mathrm{p}=0.080$ ). Data analysis shows that the direction of a positive relationship means that the higher the ferritin level, the greater the baby's weight is born where the strength of the relationship is weak $(r=0.280)$. Also obtained from the picture above that the value of $r^{2}=0.131$, which means that $13.1 \%$ ferritin levels affect the baby's birth weight, while $86.9 \%$ are again influenced by other factors.

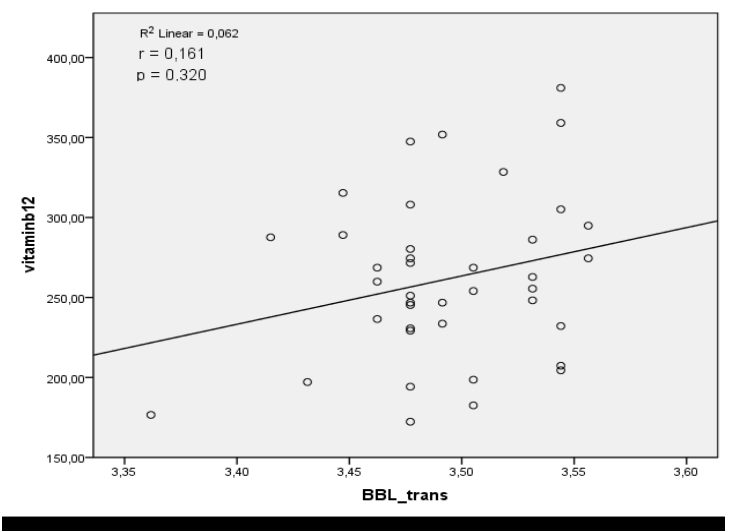

Figure 2. Scatter Plot Relation of Vitamin B12 Levels Pregnant Women Anemia with Birth Weight Weight

Based on the picture above it can be seen that there is no significant relationship between vitamin B12 levels of anemia pregnant women with birth weight (value $p=$ 0.32). Data analysis shows that the direction of a positive relationship means that the higher the level of vitamin B12, the greater the weight of the baby born where the strength of the relationship is very weak $(r=$ 0.16). Also obtained from the picture above that the value of $r^{2}=0.062$, which means that $6.2 \%$ of vitamin B12 affects the birth weight of the baby and $93.8 \%$ is again influenced by other factors such as genetic factors, environment and maternal nutritional intake during pregnancy (BMI).

\section{IV.DISCUSSION}

\section{TheRelationship between Ferritin Levels} of Pregnant Women and Anemia of Birth

\section{Babies}

The results of statistical analysis showed that there was no significant relationship ( $p=0.08$ ) between ferritin levels of anemic pregnant women on the weight of babies born with weak relationship strength $(\mathrm{r}=0.28)$ and the direction of a positive relationship is the higher the level of fertitin, the greater the baby's weight, with a value of $\mathrm{r}^{2}=0.131$, it means that ferritin levels of anemia pregnant women contribute $13.1 \%$ to the baby's birth weight while the remaining $86.9 \%$ is determined by factors others that are not examined such as genetic factors, environment and maternal nutritional intake during pregnancy (BMI).

The period from the beginning of the ninth week to birth is known as the fetal period. This period is characterized by rapid body growth and maturation of organs and tissues. body weight growth increased most rapidly in the 28th week of pregnancy (Sadler, 2013).

Ferritin is an iron reserve in the body. To function in the iron body requires transferin protein, transferrin receptor and ferritin which acts as a provider and storage of iron in the body and iron regulatory protein (IRO) to regulate iron supply. 
Ferritin functions as an iron storage protein that is nontoxic and will be mobilized when needed (Ani, 2010).

Pregnant women need additional iron to increase the number of red blood cells and form fetal and placental red blood cells. Decreased ferritin levels are associated with the reduction of maternal iron reserves due to increased needs by the mother, placenta and the fetus itself. The process of channeling iron from the mother to the fetus is regulated by involving the process of iron absorption from the mother's circulation. Iron from the mother moves across the placenta and into the fetal circulation. During pregnancy the amount of iron channeled to the fetus increases (Allen, 2000; Longo, 2013).

The placenta functions as transfortation of iron from the mother to the fetus. Iron transfer from mother to fetus is supported by a substantial increase in iron absorption during pregnancy and is regulated by the placenta. Serum transferrin carries iron from the maternal circulation for transferrin receptors located on the apical surface and placental syncytiotrophoblasts, holotransferin iron released and apotransferin returned to the maternal circulation. Iron is then free to bind ferritin in the placental cells and exit as holotrasnferin into the fetal circulation. When maternal nutritional status is lacking, the number of placental transferrin receptors increases so that more iron is taken by the placenta and transfortated for the fetus and excessive iron for the fetus can be prevented by synthesis of placenta ferritin. (Allen, 2000).

The results of this study are in accordance with the study conducted by Alifahningdyah (2013) on the correlation of hemoglobin levels, serum ferritin and transfer saturation of third trimester pregnant women with infant birth weight conducted on 220 pregnant women which showed that there was no correlation between serum ferritin in pregnant women trismester III with birth weight $(p=0.761)$. According to study conducted by Kalem et al (2016) on the effect of ferritin levels, vitamin B12 and folic acid on pregnancy output, it was found that pregnant women who experienced anemia during the third trimester had no effect on the weight of the baby born ( $p=$ $0.17)$.

The results of this study are not in accordance with the study conducted by Vjirinejad (2007) on ferritin concentration and pregnancy: a linear model to predict birth weight and birth length obtained results that there was a significant relationship between maternal serum ferritin concentration and infant body weight $(\mathrm{r}=$ $0.434, \mathrm{n}=120, p<0.001)$, in accordance with study conducted by Chawla et al (2002) on maternal and infant outcomes at maternal anemia levels, obtained results were a relationship between third trimester pregnant women who experienced anemia in the baby's birth weight but at severe anemia level $(<7 \mathrm{gr} \%)$.

Based on the results of this study which states that there is no significant relationship between serum ferritin levels of pregnant women anemic to birth weight and results of other similar studies above can be explained theoretically fetal growth increases rapidly at 28 weeks gestation. Studyers did not examine maternal nutrition during pregnancy other than that the determinant that determines the weight of newborns is not only ferritin but multifactorial, there are other factors that influence genetic and environmental factors.

Even so, it is necessary for KIE for every pregnant woman to consume fe tablets related to compliance and how to consume in order to maintain normal ferritin levels because ferritin levels not only affect the 
weight of the newborn baby but also affect metabolic processes that also support the baby's health Newborn.

Relationship of Vitamin B12 Levels of Pregnant Women Anemia with Birth Weight Weight The

Results of statistical analysis showed that there was no correlation $(p=0.32)$ between vitamin B12 levels on body weight of babies born with very weak strength ( $\mathrm{r}=$ 0.16 ) and the direction of the relationship is positive where the higher the level of vitamin B12, the greater the weight of the baby born, with a value of $r^{2}=0.062$ can be interpreted as vitamin B12 levels anemic pregnant women contribute $6.2 \%$ to the baby's birth weight and the rest is determined by other factors which were not examined such as genetic factors, environment and maternal nutritional intake during pregnancy (BMI).

Vitamin B12 is known as a guardian of appetite and prevents anemia by forming red blood cells. The role of vitamin B12 in cell formation, cobalamin deficiency can interfere with the formation of red blood cells resulting in reduced red blood cell count and result in anemia (Citrakesumasari, 2012).

Low cobalamin status can occur in pregnant women especially in late pregnancy. The decrease in vitamin B12 concentration in accordance with increasing gestational age is due to hemodilution, hormonal changes, changes in the concentration of vitamin B12 binding protein or active transport of vitamin B12 throughout the placenta (Samuel, 2013).

Vitamin B12 is needed for cell division during pregnancy and plays an important role in fetal growth. Vitamin B12 deficiency can cause megaloblastic anemia which will inhibit DNA synthesis and slow the cell cycle during erythropoesis. Red blood cells function to bind oxygen which is then distributed to all tissues and cells. Vitamin B12 deficiency is associated with impaired development and implantation of the placenta, this condition leads to a decrease in placental function as transfortation for fetal nutrition thus causing a decrease in baby's weight (Samuel, 2013).

In accordance with the study conducted by Ozturk et al (2015) on the effect of vitamin B12 levels on birth weight performed on 145 pregnant women who had Vitamin B12 deficiency showed no effect of vitamin B12 deficiency on birth weight ( $p=$ 0.321). Study reveals the limitations of studyers unable to control factors that influence vitamin B12 levels such as parity, nutrient intake before and during pregnancy, social - cultural, genetic and environmental.

Study conducted by Rogne et al (2017) on the relationship of maternal vitamin B12 concentration during pregnancy to the incidence of preterm birth and low birth weight infants found that there was no linear relationship between vitamin B12 levels of pregnant women and the weight of babies born, but vitamin B12 deficiency ( $<148$ pmol / L) higher birth rate with low birth weight babies.

This study contradicts the study conducted by Youssry et al (2017) on the effect of vitamin B12 and folic acid levels on three trimester pregnant women on fetal birth weight obtained a significant relationship ( $p$ $=0.001$ ) between vitamin B12 levels on fetal birth weight and no a significant relationship ( $p=0.132)$ between folic acid levels of third trimester pregnant women on fetal birth weight and study conducted by Ahmed et al (2011) on the relationship between folic acid and vitamin B12 pregnant women with birth weight and new body proportions born to 150 pregnant women found a relationship between folic acid and vitamin B12 of pregnant women on birth weight. 
The results of this unrelated study theoretically can be explained that the cause of the birth weight of a baby is not only a single factor but is influenced by interrelated factors such as vitamin B12. Vitamin B12 functions as an important coenzyme for two enzymatic reactions in the body. The first reaction is the reaction of methionnine synthase in which methionine synthase catalyzes methylation of Homocysteine to methionine in the cytoplasm. This reaction is important for a number of methyl transfer reactions and is involved in nucleotide synthesis. The second reaction is the methylmalony-CoA reaction in which metylmalonyl-CoA catalyzes the conversion of metylmalonyl-CoA to succinyl-CoA in mitochondria (Samuel, 2013).

On this basis, it is necessary for IEC related nutrition to be balanced for every pregnant woman to maintain the stability of the metabolic process in the body.

\section{V.CONCLUSION}

There was a positive relationship but there was no significant relationship between ferritin levels of anemic pregnant women with baby birth weight and there was a positive relationship but there was no significant relationship between vitamin B12 levels of anemic pregnant women with baby birth weight. It is recommended that pregnant women keep on consuming Fe tablets during pregnancy and further study is necessary to see pregnant woman adherence and the right time to consume Fe tablets. 


\section{DAFTAR PUSTAKA}

Allen, LH, Anemia and Iron Deficiency: Effect of Pregnancy Outcome, Am J Clin Nutr, Vol. 71, No.5, 2000, pp 1280-1284.

Ani. LS,Anemia defisiensi besi: masa hamil dan pra hamil, Jakarta: Kedokteran EGC, 2010

Ahmed. A, Akhter. M, Sharmin. S, Ara. S, Hoque. M, Relationship of maternal folic acid and vitamin B12 with birth weight and body proportion of newborn, J Dhaka National Med,Vol. 8, No. 1, 2011, pp. 7-11.

Alifaningdyah. S, Hubungan Korelasi Hemoglobin, Feritin Serum dan Saturasi Trasnferin Ibu Hamil Trimester III Dengan Berat Badan Lahir Bayi di RS PKU Muhammadiyah Bantul, Skripsi, Universitas Gajah Mada,Yogyakarta, Indonesia, 2013.

Breyman. C, Iron deficiency anemia in pregnancy. Obstet and Gynecol,Vol. 8, No. 6,2013, pp. 587-596

Chawla. M, Batra. S, Sharma. JB, Arora. R, Maternal and Perinatal Outcome in Varriying Degrees of Anemia. Int J Gynecol Obstet; Vol. 79, 2002, pp 93-100.

Citrakesumasari, Anemia Gizi: Masalah dan Pencegahannya, Yogyakarta: Kalika, 2012

Departemen Kesehatan RI. (2008). Riset Kesehatan Dasar (Riskesdas) 2007. Jakarta: Departemen Kesehatan RI

Dinas Kesehatan Kota Padang.(2015). Profil Kesehatan Kota Padang Tahun 2014. Padang: Dinas Kesehatan Kota padang

Dinas Kesehatan Provinsi Sumatra Barat.(2015). Profil Kesehatan Sumatra Barat.Tahun 2014. Padang: Dinas Kesehatan Provinsi Sumatra Barat.

Gebre. A dan Mulugeta. A, Prevalence of Anemia and Associated Factors among Pregnant Women in North Western Zone of Tigray, Northern Ethiopia: A Cross-Sectional Study, Journal Of Nutrition and Metabolism, 2015, pp. 1-7

Kalem. P, Benli. AR, Koroglu. M, Benli. NC, Koyuncu. M, Cesur. O. et al, The effecy of ferritin, vitamin B12 and folic acid on pregnancy outcomes, Int J Clin Exp Med, Vol. 9, No 11, 2016, pp. 22413-22417.

Kementerian Kesehatan RI. (2014). Survei Demografi dan Kesehatan Indonesia Tahun 2012. Jakarta: Kementerian Kesehatan RI

Longo, DL. Harrison's Hematology and Oncology, United States: The McGraw-Hill Companies, 2013

Ronge, T., Tielemans, MJ., Yjnik, CS., Chong, MF., Krishnaveni, GV., Poston, L et al, Maternal Vitamin B12 in pregnancy and risk of preterm birth and low birth weight: A systematic 
review and individual participant data metanalysis, Am J Epidemiol, Vol 185, No 3, 2017, pp. $212-223$.

Sadler. TW, Embriologi Kedokteran Ed.12, Jakarta: EGC, 2013

Samuel. TM,Maternal micronutrient deficiencies in early pregnancy and infant nutritonal status in urban South India, Thesis, Universirty Of Tempere, Tempere, Finlandia, 2013.

Tarwoto\&Wasnida,Anemia Pada Ibu Hamil Konsep dan Penatalalaksanaan, Jakarta: Trans Info Medika, 2007.

Visnjevac, N., Segedi, LM., Curcic, A., Visnjevac, J., Stajic, D, Blood ferritin levels in pregnant women and prediction of the development of fetal intrauterine growth restriction, $\mathrm{J} \mathrm{Med}$ Biochem, Vol. 30, No. 4,2011, pp. 317-322.

Vjirinejad, R., Esmaeili, A., Vijrinejad, H., Hassanshahi, G, Ferritin concentration and pregnancy outcome: linear models for predicting birthweight and birth length,Food and nutrition bulletin, Vol. 28, No. 4, 2007, pp. 419-425.

WHO. (2011). Worldwide Prevalence of Anemia: WHO Global Database on Anemia. Geneva, Switzerland: World Health Organization Press

WHO. (2011). Haemoglobin concentrations for the diagnosis of anaemia and assessment of severity. Vitamin and Mineral Nutrition Information System. Geneva: World Health Organization.

WHO. (2011). Serum ferritin Concentrations for the assessment of iron status and iron deficiency in populations. Vitamin and mineral nutrition information system. Geneva: World Health Organization. 